\title{
Peran Audit Internal Pada Efektivitas Pengendalian Internal Mendukung Kredit Investasi Di Cabang BRI Di Situbondo
}

\author{
Ratih Rachmawati
}

STIE Mandala Jember

\begin{abstract}
Purpose of this research is to obtain a picture of the effectiveness of intenal audit and how the role of internal audit in supporting the effectiveness of the investment credit control.The method used in this research is descriptive analysis method, where data obtained by the author analyzed and compared with some existing theories. Based on the results of the research authors conclude that the overall implementation of internal audit in the branch branch Bank Rakyat Indonesia in Situbondo for credit monitoring activities have been adequate for investment in accordance with the rules and policies set by the central office, but it also includes compliance, verivication and evaluation. Thus, these findings have been in accordance with the propositions that have been made in the implementation of the study conducted internal audits can adequately support the achievement of the effectiveness of internal control in the process of granting investment credits the branch branch Bank Rakyat Indonesia in Situbondo
\end{abstract}

Keywords : Internal Audit role, Internal control system, Investment credit

\section{PENDAHULUAN}

Dalam usaha mewujudkan tujuan pembangunan nasional yang merata dan dapat dinikmati oleh seluruh rakyat, maka pemerintah mengarahkan khususnya pada bidang ekonomi, dimana pemerintah memberikan bimbingan dan pengarahan terhadap pertumbuhan ekonomi serta menciptakan iklim yang sehat bagi perkembangan di dunia usaha yang dilaksanakan melalui langkah-langkah dan kebijaksanaan untuk mencapai laju pertumbuhan ekonomi nasional sesuai dengan yang diharapkan.

Corresponding Author:

Email : ratih@stie-mandala.ac.id 
Diantara berbagai kebijakan ekonomi yang dilaksanakan, bidang perbankan merupakan salah satu bidang yang mendapat perhatian pemerintah karena bank merupakan salah satu sumber permodalan yang sangat dibutuhkan oleh masyarakat dalam menjalankan kegiatan usahanya. Sehingga bank dituntut peran sertanya untuk mensukseskan pembangunan melalui jasa kredit yang sangat dibutuhkan masyarakat.

Pemberian kredit sangat berguna bagi masyarakat karena dapat meningkatkan perekonomian mereka dalam daya guna suatu barang atau jasa. Salah satu jenis kredit yang diberikan bank adalah kredit investasi. Dalam hal ini kredit investasi merupakan bantuan dari pihak bank yang diberikan pada para pengusaha untuk keperluan investasi yaitu untuk kegiatan yang erat hubungannya psikologis yang terjadi. Dengan adanya kredit macet, kegiatan bank akan terhambat sebab keuntungan utama bank diperoleh dari selisih bunga simpanan bank kepada nasabah dengan bunga pinjaman atau kredit yang disalurkan. Selain itu, dampak psikologis yang akan terjadi adalah menurunnya tingkat kepercayaan masyarakat terhadap bank. Masalah tingginya jumlah kredit macet sangat meresahkan masyarakat terutama masyarakat perbankan, karena hal tersebut berkaitan dengan kredibilitas bank. Sebagian dari kredit macet yang diserahkan bank-bank terutama milik pemerintah kepada Badan Penyehatan Perbankan Nasional (BPPN) tidak jelas statusnya.

Tingkat persaingan antar bank dan risiko perkreditan yang tinggi menyebabkan pihak manajemen bank perlu menerapkan suatu pengendalian internal yang memadai. Pengendalian internal yang memadai pada dasarnya bertujuan untuk melindungi harta milik perusahaan dengan meminimalkan kemungkinan terjadinya penyelewengan, pemborosan, kemacetan kredit, serta meningkatkan efisiensi dan efektifitas kerja. Oleh karena itu perlu dilakukan evaluasi terhadap pengendalian internal, yaitu dengan melakukan pemeriksaan internal atau audit internal. Audit internal adalah fungsi penilaian yang independen yang ditetapkan oleh organisasi untuk memeriksa dan mengevaluasi secara obyektif aktivitas-aktivitas organisasi, yang hasil penelitiannya berupa saran, rekomendasi, analisis, dan informasi akan 
bermanfaat bagi manajemen dalam mengusahakan agar perusahaan berjalan dengan baik untuk mencapai tujuan yang telah ditetapkan sebelumnya.

Berdasarkan uraian di atas, penulis merasa tertarik untuk menyusun karya penelitiannya dengan judul: " Peranan Audit Internal dalam menunjang Efektifitas Pengendalian Internal Kredit Investasi pada the Branch Bank Rakyat Indonesia in Situbondo."

Berdasarkan latar belakang tersebut maka masalah yang akan diidentifikasi adalah "Bagaimana peran audit internal dalam menunjang efektifitas pengendalian internal terhadap masalah pemberian kredit investasi the Branch Bank Rakyat Indonesia in Situbondo.

\section{TINJAUAN PUSTAKA}

\section{Peneliti tedahulu}

Dalam melakukan penelitian ini, peneliti memperoleh rujukan dari:

Penelitian Terdahulu

Iriyadi (2004), dalam penelitiannya mengenai peranan internal auditor dalam menunjang efektifitas sistem pengendalian intern penggajian pada PT. Organ Jaya, dalam penelitiannya permasalahan yang diangkat yaitu apakah peranan internal auditor dalam perusahaan tersebut telah memadai dan bagaimana peranan internal auditor dalam menunjang efektifitas sistem pengendalian internal penggajian. Metode penelitian yang digunakan dalam penelitian ini adalah studi kasus dengan menggunakan metode analisis deskriptif. Kesimpulan dari penelitian ini adalah bahwa penerapan audit internal berpengaruh signifikan terhadap efektifitas pengendalian internal perusahaan. Hal itu terbukti ketika dilakukan evaluasi pengawasan internal pada divisi pembagian umum bahwa tanggung jawab untuk waktu pencatatan dan menyiapkan daftar gaji ditemukan kesalahan yaitu daftar jam kerja palsu dan daftar fiktif gaji pewagai perusahaan. Pengawas intern yang dimiliki perusahaan mempunyai kedudukan yang independen terhadap bagian-bagian yang diperiksanya. Hal ini terlihat dengan tidak terlibatnya pengawas intern terhadap salah satu fungsi yang ada pada perusahaan. 
Persamaan: Pada penelitian terdahulu dan penelitian sekarang sama-sama meneliti tentang peran auditor internal dalam menunjang efektifitas sistem pengendalian intern perusahaan. Metode yang dipakaipun sama yaitu analisis deskriptif.

Perbedaan: Pada penelitian terdahulu peneliti mencoba untuk mengetahui peran auditor internal dalam pengendalian internal pada bagian penggajian perusahaan, sedangkan peneliti saat ini mencoba untuk meneliti peran audit internal dalam efektifitas pengendalian internal kredit investasi perusahaan. Obyek yang digunakan dalam penelitian terdahulu adalah perusahaan dagang yaitu PT. Organ Jaya, sedangkan dalam penelitian saat ini menggunakan the Branch Bank Rakyat Indonesia in Situbondo

Ihsan Kusumah (2008), dalam penelitiannya tentang peranan audit internal dalam pencegahan fraud. Tujuan penelitian ini adalah untuk mengetahui apakah pelaksanaan audit internal telah dilaksanakan secara memadai, dan apakah pelaksanaan audit internal dapat berperan dalam pencegahan kecurangan di Kantor Cabang Utama PT. Bank Jabar. Metode penelitian yang digunakan adalah metode studi kasus. Dapat disimpulkan bahwa audit internal bermanfaat dalam pencegahan kecurangan (Fraud). Untuk mencegah terjadinya fraud pada perusahaan, penulis mengajukan saran bahwa audit internal hendaknya terus-menerus meninjau dan melakukan tindak lanjut audit untuk memastikan apakah tindakan perbaikan untuk mengatasi kelemahan-kelemahan yang ditemukan dalam audit sudah dilaksanakan oleh manajemen, audit internal hendaknya memahami dan mengerti kegiatan auditee, dalam hal mengevaluasi sistem pengendalian intern, sehingga kegiatan auditee dapat dimaksimalkan, dan kecurangan dapat dihindarkan, serta kinerja auditor internal PT. Bank Jabar Banten hendaknya terus ditingkatkan agar dapat mengetahui dan menghindari terjadinya kecurangan. Persamaan : Pada penelitian terdahulu dan penelitian sekarang sama-sama meneliti tentang peranan auditi internal dan obyek penelitiannya sama-sama merujuk pada Bank . 
Perbedaan : Pada penelitian terdahulu peneliti mencoba untuk mengetahui peranan audit internal dalam hal pencegahan terjadinya kecurangankecurangan (fraud) dalam segala bagian, sedangkan pada penelitian saat ini, hanya dibatasi pada bagian kredit investasi. yang menghubungkan antara manajemen bank, yang terutama bertanggung jawab untuk menilai suatu sistem pengendalian internal yang sesuai, dan otoritas pengawas, seperti internal dan eksternal auditor, dan supervisor. stabilitas sistem perbankan secara keseluruhan di Negara Rumania. Sedangkan peneliti saat ini mencoba meneliti peran audit internal dalam menunjang pengendalian intern Bank di Indonesia.

\section{Audit internal.}

Menurut Institute of Internal Auditors mengenai pengertian audit internal "Internal auditing is an independent appraisal function established within an organization to examine and evaluate its activities as a service in the organization.." Dari pengertian tersebut kita dapat menyimpulkan tujuh kunci audit internal, yaitu:

1. Independent

Bahwa audit bersifat bebas dari pembatasan ruang lingkup dan efektivitas hasil audit yang berupa temuan dan pendapat.

\section{Appraisal}

Bahwa keyakinan penelitian audit atas kesimpulan yang dibuatnya.

3. Established

Pengakuan perusahaan atas peranan audit internal.

4. Examine and evaluate

Bahwa kegiatan audit internal sebagai auditor menguji serta menilai terhadap fakta-fakta yang ditemukan dalam perusahaan.

\section{Its Activities}

Bahwa ruang lingkup pekerjaan audit internal mencakup seluruh aktivitas organisasi.

6. Services

Bahwa dalam intinya audit internal berusaha untuk membantu 
manajemen dalam melaksanakan fungsi pengendalian, oleh karena itu hasil pekerjaan audit internal pun harus diserahkan kepada manajemen.

7. To the Organization

Ruang lingkup pelayanan audit internal ditujukan kepada seluruh bagian organisasi, termasuk semua personil perusahaan, dewan komisaris dan pemegang saham.Sedangkan pengertian audit internal menurut Mulyadi (1998;202) adalah sebagai berikut: Audit internal merupakan kegiatan penilaian bebas yang terdapat dalam organisasi, yang dilakukan dengan cara memeriksa akuntansi keuangan dan kegiatan lain untuk memberikan jasa bagi manajemen dalam melaksanakan tanggung jawab mereka dengan cara menyajikan analisis penilaian, rekomendasi dan komentar-komentar penting terhadap kegiatan manajemen. .

\section{Fungsi audit internal}

Menurut Mulyadi dan Kanaka $(1998 ; 202)$ mendefinisikan Fungsi audit internal adalah "Menyediakan jasa analisis dan evaluasi juga memberikan keyakinan dan rekomendasi serta informasi lain kepada manajemen dan dewan komisaris serta pihak lain yang memiliki wewenang dan tanggungjawab yang setara." Fungsi audit internal yang terperinci dan relatif lengkap menunjukkan bahwa aktivitas audit internal harus diterapkan secara menyeluruh terhadap seluruh aktivitas perusahaan, sehingga tidak hanya terbatas pada audit atas catatan-catatan akuntansi. Divisi audit internal merupakan bagian integral dari organisasi dan berfungsi sesuai dengan kebijaksanaan yang telah ditetapkan oleh manajemen senior dan atau dewan. Tujuan, kewenangan, dan tanggungjawab divisi audit internal harus dinyatakan dalam dokumen tertulis yang formal, misalnya dalam anggaran organisasi. Anggaran organisasi harus menerangkan tentang tujuan divisi audit internal, menegaskan lingkup pekerjaan yang tidak dibatasi, dan menyatakan bahwa divisi audit internal tidak memiliki kewenangan atau tanggung jawab dalam kegiatanyang mereka periksa.

\section{Tujuan dan Ruang Lingkup Audit Internal.}

Audit internal bertujuan untuk membantu semua bagian dalam perusahaan agar dapat melaksanakan fungsinya secara efektif dan efisien. Audit internal 
akan memberikan penilaian, pandangan ataupun saran-saran yang akan dapat membantu semua bagian dalam perusahaan untuk melaksanakan aktivitasnya dengan baik.

Menurut Hiro Tugiman $(1997 ; 11)$ tujuan audit internal adalah sebagai berikut : Tujuan dasar audit internal adalah untuk membantu para anggota organisasi agar dapat menyelesaikan tanggung jawabnya secara efektif, untuk tujuan tersebut, pengawasan internal menyediakan bagi mereka berbagai analisis, penilaian, rekomendasi, nasihat dan informasi sehubungan dengan aktifitas yang diperiksa. Untuk mencapai tujuan tersebut, audit internal harus melakukan kegiatan-kegiatan berikut :

1. Menelaah dan menilai kebaikan penerapan dari sistem pengendalian manajemen, pengendalian internal dan pengendalian operasional lainnya serta mengembangkan pengendalian yang efektif dengan biaya yang tidak terlalu mahal.

2. Memastikan ketaatan terhadap kebijakan, rencana-rencana, dan prosedurprosedur yang telah ditetapkan oleh manajemen.

3. Memastikan seberapa jauh harta perusahaan dipertanggungjawabkan dan dilindungi dari kemungkinan terjadinya segala bentuk pencurian, kecurangan dan penyalahgunaan.

4.Memastikan bahwa pengelolaan data yang dikembangkan dalam organisasi dapat dipercaya.

5. Menilai mutu pekerjaan setiap bagian dalam melaksanakan tugas-tugas yang diberikan oleh manajemen.

6. Menyarankan perbaikan-perbaikan operasional dalam rangka meningkatkan efisiensi dan efektivitas. Audit internal meliputi evaluasi dan pemeriksaan atas efektifitas pengendalian serta kualitas pelaksanaan tugas setiap personil.

\section{Wewenang dan Tanggung jawab Audit internal.}

Tanggung jawab penting fungsi audit internal adalah memantau kinerja pengendalian internal dalam perusahaan. Pada waktu auditor berusaha memahami pengendalian internal, ia harus berusaha memahami fungsi audit 
internal untuk mengidentifikasi aktivitas audit internal yang relevan dengan perencanaan audit.

Lingkup prosedur yang diperlukan untuk memahaminya bervariasi, tergantung atas sifat aktivitas audit internal tersebut. Tanggung jawab seorang audit internal menurut Komite SPAP Ikatan Akuntan Indonesia dalam Standar Profesi Akuntan Publik (2004;322.1) yaitu : Auditor internal bertanggung jawab untuk menyediakan jasa analisis dan evaluasi, memberikan keyakinan dan rekomendasi dan informasi lain kepada manajemen entitas dan bagian komisaris atau pihak lain yang setara wewenang dan tanggung jawabnya. Untuk memenuhi tanggung jawabnya tersebut auditor intern mempertahankan obyektivitasnya yang berkaitan dengan aktivitas yang diauditnya. Wewenang yang dapat ditetapkan bagi auditor internal antara lain:

1. Menyusun program audit internal secara menyeluruh atau semua aktifitas dalam perusahaan.

2. Menguji keandalan pengendalian manajemen.

3. Tanpa batasan untuk memasuki semua bagian perusahaan, meneliti catatan, pelaporan serta harta milik perusahaan.

\section{Program Audit Internal.}

Dalam program audit internal, untuk dapat melakukan audit yang sistematis dan terarah maka pada saat audit dimulai, audit intenal terlebih dahulu menyusun suatu perencanaan atau program audit yang akan dilakukan. Program audit ini dapat dipergunakan sebagai alat perencanaan dan pengawasan yang efektif atas pekerjaan audit secara keseluruhan. Mulyadi mengemukakan pentingnya program audit, Bahwa audit diperlukan untuk pengawasan dan pengarahan atas aktifitas audit yang dilakukan oleh audit internal dengan maksud untukmemperoleh efisiensi dan efektifitas audit (Mulyadi,1998;82). Sedangkan menurut Hiro Tugiman (1997;58) dalam program audit haruslah :

1. Membuktikan prosedur audit dalam pengumpulan, analisis, penafsiran dan penyimpangan informasi yang diperoleh selama audit.

2. Menetapkan tujuan audit. 
3. Menyatakan lingkup dan tingkat pengujian yang diperlukan untuk mencapai tujuan audit.

4. Mengidentifikasi aspek-aspek teknis, resiko, proses dan transakasi yang akan diteliti.

5. Menetapkan sifat, luas pengujian yang diperlukan.

6. Merupakan persiapan bagi awal pelakssanaan pekerjaan.

\section{Tahap-tahap Audit Internal}

Tahap-tahap pelaksanaan audit internal menurut Hiro Tugiman (1997;53) adalah sebagai berikut:

1. Perencanaan Pemeriksaan

Perencanaan audit internal harus didokumentasikan yang meliputi hal-hal berikut ini:

a. Penetapan tujuan audit dan lingkup pekerjaannya.

b. Memperoleh informasi dasar (background information) tentang kegiatan yang diaudit.

c. Penentuan tenaga yang diperlukan untuk melaksanakan audit.

d. Pemberitahuan kepada para pihak yang dipandang perlu.

e. Melaksanakan survei secara tepat untuk lebih mengenali kegiatan yang diperlukan, risiko-risiko dan pengawasan pengawasan untuk mengidentifikasi area yang ditekankan dalam audit, serta untuk memperoleh berbagai alasan dan sasaran dari pihak yang akan diperiksa.

2. Pengujian dan Pengevaluasian Informasi Audit internal harus mengumpulkan, menganalisis, menginterprestasikan dan membuktikan kebenaran informasi untuk mendukung hasil audit.

3. Pemberitahuan Hasil

Auditor internal harus melaporkan hasil audit yang dilakukannya setelah audit selesai dilaksanakan. Suatu laporan harus obyektif, jelas, singkat, konstruktif dan tepat waktu. Laporan haruslah mengemukakan tentang maksud, lingkup dan hasil pelaksanaan pemeriksaan, bila dipandang perlu dapat pula dicantumkan pernyataan tentang pendapat pemeriksa. 
4. Tindak Lanjut (Follow Up) Auditor internal harus terus meninjau dan melakukan tindak lanjut (follow up) untuk memastikan bahwa temuan audit yang dilaporkan telah dilakukan tindakan yang tepat.

\section{Laporan Hasil Audit Internal}

Laporan hasil audit internal dibuat setelah audit dilakukan. Laporan merupakan hal yang sangat penting karena dalam laporan ini auditor internal menuangkan seluruh hasil pekerjaannya dan merupakan realisasi dari tanggung jawab auditor internal untuk menginformasikan hasil pengukuran aktivitas perusahaan yang telah diauditnya.

Hiro Tugiman (1997;68) menyatakan bahwa auditor internal harus melaporkan hasil audit yang dilakukannya dengan memperhatikan hal-hal berikut ini:

1. Laporan tertulis yang telah ditandatangani dikeluarkan setelah pengujian terhadap pemeriksaan selesai dilakukan, sedangkan laporan sementara dapat dibuat secara tertulis maupun lisan dan diserahkan secara formal atau informal

2. Sebelum laporan itu diterbitkan, auditor harus terlebih dahulu mendiskusikan berbagai kesimpulan dan rekomendasi dengan tingkatan manajemen, sebelum mengeluarkan laporan akhir.

3. Laporan harus obyektif, ringkas, jelas, konstruktif dan tepat waktu.

4. Laporan harus mengemukakan tentang maksud, lingkup dan hasil pelaksanaan pemeriksaan, bila dipandang perlu laporan harus berisikan pernyataan tentang pendapat auditor.

5. Laporan dapat mencakup rekomendasi yang membangun dan menyatakan hasil serta tindakan koreksi yangmemuaskan.

6. Laporan harus mencakup pandangan dari pihak yang diperiksa tentang berbagai kesimpulan atau rekomendasi dan dapat pula dicantumkan dalam laporan audit.

7. Laporan harus disetujui oleh kepala bagian auditor internal sebelum diterbitkan serta harus menyatakan kepada siapa laporan tersebut ditujukan. 


\section{Tindak Lanjut Atas Laporan}

Hasil Audit Internal Oleh Manajemen Setelah laporan hasil audit internal diberikan kepada auditee, proses audit belum benar-benar selesai. Langkah selanjutnya dari proses audit adalah tindak lanjut atas laporan hasil audit internal oleh manajemen. Tiga bentuk umum tindak lanjut pihak manajemen menurut The Institute of Internal

Auditors terdiri dari:

1. Manajemen puncak melakukan konsultasi dengan auditee untuk memutuskan jika, kapan, dan bagaimana rekomendasi auditor internal dilaksanakan.

2. Auditee melakukan tindakan atas keputusan tersebut.

3. Auditor internal bersama auditee melakukan pengecekan kembali untuk melihat apakah tindakan perbaikan telah di ambil dan hasil yang diinginkan tercapai, atau manajemen dan komite audit telah menerima tanggung jawab apabilia tidak melakukan tindakan perbaikan tersebut.

\section{Pengertian Efektifitas}

Menurut Arens dan Loebbecke (2000;789) adalah sebagai berikut Effevtiveness refers to the accomplishment of obyectives, whereas efficiency refers to the resource used to achive those obyective. An example of effectiveness is the production of parts without defects. Efficiency concerns whether those parts are produced at minimum cost.

\section{Pengendalian Internal}

Pengedalian internal menurut Mulyadi (1998;171) yaitu: Pengendalian internal adalah suatu proses yang dipengaruhi oleh dewan komisaris, manajemen, personel satuan usaha lainnya, yang dirancang untuk mendapatkan keyakinan memadai tentang pencapaian tujuan dalam hal keandalan pelaporankeuangan, kesesuaian dengan undang-undang dan peraturan yang berlaku, efektivitas dan efisiensi operasi. Konsep yang terkandung dalam definisi ini adalah:

1. Pengendalian intern adalah suatu proses. Pengendalian intern merupakan cara untuk mencapai tujuan, bukan untuk tujuan itu sendiri. 
2.Pengendalian intern dipengaruhi oleh manusia. Pengendalian intern bukan hanya terdiri dari buku pedoman kebijakan dan formulir-formulir, tetapi juga orang-orang pada berbagai jenjang dalam suatu organisasi,termasuk dewan komisaris, manajemen, serta personel lainnya.

3.Pengendalian intern diharapkan memberikan keyakinan memadai, bukan keyakinan penuh.

4. Pengendalian intern adalah alat untuk mencapai tujuan, yaitu pelaporan keuangan, kesesuaian dan operasi.

\section{Kerangka Pemikiran}

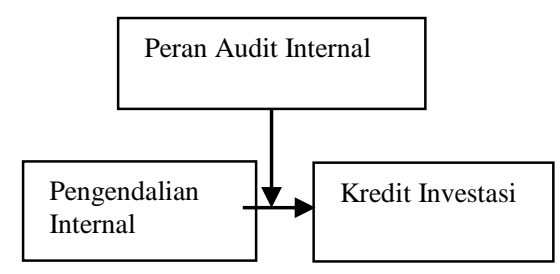

Gambar 2.1. Bagan Rerangka Pemikiran

\section{Proposisi Penelitian}

Dengan demikian berdasarkan uraian tersebut maka ditetapkan proposisi penelitian sebagai berikut : "Pelaksanaan audit internal yang dilaksanakan dengan memadai dapat mendukung tercapainya efektifitas pengendalian internal dalam proses pemberian kredit investasi Bank Rakyat Indonesia Cabang di Situbondo". Kredit Investasi Pengendalian Internal

\section{PEMBAHASAN}

Pembahasan hasil wawancara

Dalam penelitian studi kasus ini peneliti melakukan observasi, berdiskusi dan melayangkan beberapa pertanyaan karena penelitian ini bersifat kuantitatif yaitu mendiskripsikan apa yang terjadi di lapangan. Berikut adalah tanggapan atas pertanyaan-pertanyaan hasil dari proses wawancara:

1. Apakah dengan dilakukannya audit internal dapat menjamin kualitas/kebenaran informasi tentang kredit investasi yang dibutuhkan oleh manajemen? seperti kewajaran dokumen-dokumen, catatan, informasi nasabah, dll. Dengandilakukannya audit internal di bidang kredit dapat meningkatkan kualitas pemberian kredit ataupun kebenaran informasi tentang 
kredit yang dibutuhkan oleh manajemen. Sedangkan untuk menjamin kualitas/kebenaran informasi kredit diperlukan verifikasi secara rutin oleh bagian supervisor kredit berupa dokumen-dokumen, catatan, informasi nasabah, dll. yang berfungsi sebagai verifikator, juga oleh pemutus kredit dengan tetap

memperhatikan prinsip-prinsip prudential banking sebelum kredit diputus/dicairkan. Fungsi internal audit/internal control pada dasarnya bertujuan untuk menilai efektivitas pelaksanaan pengendalian internal yang dilakukan oleh unit kredit tersebut. Pelaksanaan audit dilakukan secara berkala dengan sampling data yang ditentukan ataupun dengan surprise audit apabila dipandang penting untuk dilakukan (bersifat urgent).

2. Apakah dengan adanya audit internal dapat menilai ketaatan pegawai/karyawan bagian kredit investasi terhadap prosedur dan kebijakan yang ada pada perusahaan? Pelaksanaan audit internal dapat menilai ketaatan pegawai atau karyawan bagian kredit investasi terhadap prosedur dan kebijakan. Para pegawai dapat patuh dan tidak satupun prosedur yang dilewatkan dalam proses pemberian kredit. Sehingga para pegawai dapat melakukan pekerjaan dengan baik sesuai dengan prosedur yang ada sehingga nantinya akan mengakibatkan berkurangnya hubungan spesial dengan para calon nasabah kredit.

3. Apakah kegiatan audit internal dapat mendeteksi kelemahan-kelemahan ataupun kekurangan terhadap prosedur kredit investasi yang ada dalam perusahaan? pelaksanaan audit internal / internal control berfungsi untuk mendeteksi dan menilai kelemahan/kekurangan terhadap prosedur kredit yang ada yang disesuaikan dengan kondisi perusahaan, persaingan bisnis, ataupun hal-hal lain yang sedang berkembang. Selain itu juga berfungsi untuk menilai pemberian kredit apakah sudah sesuai dengan prosedur/ aturan/ kebijakan yang telah ditentukan perusahaan.

4. Bagaimana audit internal dapat memberikan pengaruh besar terhadap pengendalian internal kredit investasi yang sedang berjalan? Fungsi audit internal/internal control dapat memberikan pengaruh besar terhadap pelaksanaan internal control dalam pemberian kredit kepada debitur dengan 
pertimbangan seperti kondisi perusahaan, persaingan bisnis, ataupun hal-hal lain yang sedang berkembang. Sehingga selain menilai pelaksanaan ketaatan (compliance) terhadap prosedur/ aturan/ kebijakan yang telah ditentukan perusahaan, juga menilai mitigasi resiko yang telah dilakukan dalam pemberian kredit meskipun sedikit menyimpang/ belum diatur dalam prosedur/ aturan/ kebijakan, serta selain itu dapat berfungsi sebagai penghubung (catalyst) antara unit kredit dengan manajemen selaku pembina sistem melalui usulan yang diberikan oleh bagian internal audit/internal control kepada manajemen berdasarkan fakta-fakta yang ditemukan di lapangan maupun isu/hal-hal yang sedang berkembang di masyarakat. Berdasarkan hasil dari observasi, wawancara dan pertanyaan yang diajukan peneliti kepada pihak-pihak yang berkepentingan dalam penelitian ini, maka peneliti memperoleh hal-hal berikut : 1. Audit internal pada perusahaan a) Kedudukan Regional Internal Control (auditor internal) dinilai independen dan obyektif karena tidak terlibat langsung dalam aktivitas operasional yang rutin sehingga dapat melaksanakan tugasnya dengan baik dan bertanggungjawab langsung kepada Manajer Regional (Kepala Kanwil). Audit internal pada perusahaan

b) Ruang lingkup audit yang telah dilaksanakan telah mencakup compliance, verifikasi, dan evaluasi terhadap kebijakan dan prosedur yang ada di PT. Bank Mandiri (Persero) Tbk

c) Adanya program audit yang merupakan pedoman bagi auditor internal dalam melaksanakan audit agar audit yang dilakukan tersusun dan terencana dengan baik.

d) Laporan audit dibuat setelah audit dilakukan, laporan tersebut berisi temuan hasil audit, rekomendasi dan saran mengenai kelemahan yang ditemukan dengan melampirkan bukti-bukti yang diperoleh.

e) Adanya tindak lanjut bagian atau obyek yang diperiksa atas saran dan rekomendasi yang diberikan oleh tin audit RIC (audit internal) dan kemudian dilakukan pemantauan terhadap tindak lanjut perbaikan yang dilaksanakan bagian yang bersangkutan oleh audit internal. 
2. Pengendalian internal pemberian kredit pada PT. Bank Mandiri dilaksanakan oleh semua bagian yang terkait mulai dari staf marketing yang mencari calon nasabah kredit yang potensial dan atau calon nasabah kredit yang datang sendiri. Pada tahap ini staf marketing menilai proposal calon nasabah yang kemudian jika dinilai sudah cukup baik diteruskan oleh bagian staf kredit untuk kemudian ditelaah kembali semua persyaratan dokumentasi. Kemudian dinilai agunan yang dijaminkan oleh bagian appraisal, setelah ini supervisor kredit menelaah kembali semua data dan jika sudah lengkap dan memadai diteruskan untuk mintapersetujuan komite Pengendalian internal pemberian kredit yaitu wakil pimpinan cabang bidang pemasaran dan atau pimpinan cabang pembantu. Pimpinan cabang memutuskan jika plafond kredit sesuai dengan batas wewenang memutus kredit (BWMK) apakah kredit diterima

atau ditolak. Pengendalian internal pemberian kredit pada perusahaan Tahapan proses pemberian kredit diatas dilakukan untuk menjaga terlaksananya pengendalian internal pemberian kredit yang efektif pada Bank Rakyat Indonesia cabang Situbondo. Keberadaan auditor internal dalam hal ini tim audit RIC Bank Rakyat Indonesia mempunyai peranan yang penting dalam menunjang efektifitas pengendalian internal pemberian kredit investasi melalui kegiatannya memeriksa dan mengumpulkan data yang cukup dengan teknik pengambilan sampel yang memadai pada setiap proses yang harus dilalui dalam pemberian kredit sehingga bagian-bagian yang terkait dalam proses pemberian kredit pun menjadi lebih hati-hati dan berusaha menjaga proses pemberian kredit sesuai prosedur.

3. Kredit merupakan usaha pokok bagi setiap bank, dimana dari kredit ini dapat ditarik keuntungan yaitu selisih antara bunga yang diterima dengan pokok yang dikeluarkan kredit merupakan sumber pendapatan utama dari suatu bank. Jika tidak dilakukan pengendalian terhadap kredit, akan ada peluang besar timbulnya penyelewengan dan penyalahgunaan yang tentunya sangat merugikan bagi bank. Oleh karena itu manajemen harus menerapkan suatu alat untuk mengendalikan kredit, khususnya kredit investasi yaitu dengan adanya fungsi audit internal. Peranan audit internal dalam menunjang 
efektivitas. pengendalian internal pemberian kredit. Pelaksanaan audit internal atas kredit investasi Bank Rakyat Indonesia Cabang Situbondo Kantor Wilayah VIII Surabaya yang didasarkan pada program audit, dapat mencerminkan pengendalian internal yang dilakukan terhadap bagian kredit khususnya kredit investasi. Berdasarkan pelaksanaan audit tersebut, maka dapat dilihat sampai sejauh mana audit yang dilakukan dapat berperan dalam menunjangefektivitaspengendalian internal kredit/ investasi, hal tersebut meliputi:

a) Compliance

Tim Audit RIC perkreditan melakukan penilaian ketaatan para karyawan bagian perkreditan terhadap prosedur yang telah ditetapkan oleh perusahaan, apakah telah dilaksanakan dengan benar.

b) Verifikasi

Dalam hal verifikasi, tim audit RIC perkreditan melakukan audit terhadap kebenaran dokumen-dokumen, catatan-catatan dan laporan-laporan pemberian kredit,

dan bagian analisis kredit, adapun dokumen yang diperiksa seperti:

bukti-bukti aplikasi kredit.

c) Evaluasi

Tim Audit RIC bagian perkreditan mengawasi apakah perkreditan yang telah dilaksanakan dengan benar sesuai dengan sistem, prosedur, dan kebijakan yang telah ditentukan oleh perusahaan. Apabila terdapat penyimpangan maka auditor internal harus segera melaporkan kepada kepala cabang. Selain itu auditor internal juga memberikan saran-saran atau rekomendasi untuk memperbaiki penyimpangan-penyimpangan yang terjadi. Auditor internal melakukan penilaian secara terus menerus terhadap pelaksanaan perkreditan yang terjadi. Audit internal mempunyai peranan yang sangat penting dalam menunjang

efektifitas pelaksanaan pemberian kredit pada Bank Rakyat Indonesia Cabang Situbondo. Hal ini dilakukan untuk menciptakan suatu pelaksanaan pemberian kredit yang sehat dan teratur sehingga akan memperkecil resiko yang akan dihadapi oleh perusahaann atas kredit yang disalurkannya. Tim 
audit internal RIC Bank Rakyat Indonesi Cabang Situbondo dapat meningkatkan efektivitas pengendalian internal pemberian kredit investasi benar-benar diyakini telah memadai karena sebagian besar pelaksanaannya masuk dalam kriteria-kriteria audit internal yang memadai sebagai berikut:

1. Sudah terdapat struktur organisasi serta uraian tugas, wewenang dan tanggungjawab dari bagian audit internal.

2. Kedudukan audit internal dalam organisasi telah ditempatkan sedemikian rupa sehingga auditor internal dapat menjalankan independensi secara penuh.

3. Adanya program audit yang menunjukkan apa yang telah dicapai serta saran perbaikan

4. Adanya program audit yang disusun dengan baik, sehingga dapat tercapai tujuan audit yang diharapkan.

5. Hasil audit staf audit internal yang disertai dengan saran tindakan perbaikan mendapat dukungan dari manajemen untuk ditindaklanjuti sampai tujuan audit internal tercapai. Jadi tim audit RIC Bank Mandiri yang memadai sangat berperan dalam meningkatkan efektivitas pengendalian dalam hal ini khususnya pengendalian internal pemberian kredit investasi. Selanjutnya pengendalian internal pemberian kredit akan efektif bilamana adanya unsur pengendalian internal yaitu pengendalian penetapan risiko, efektivitas pengendalian, informasi dan komunikasi, serta monitoring. Untuk mengatasi keterbatasan-keterbatasan pada pemberian kredit investasi, maka Tim audit RIC bidang perkreditan dan manajemen secara terus menerus mengevaluasi dan menilai pelaksanaan pemberian kredit pada PT. Bank Mandiri agar tujuan perusahaan dapat tercapai.

\section{KESIMPULAN DAN SARAN}

\section{Kesimpulan}

Berdasarkan hasil pembahasan dari data yang diperoleh melalui observasi,wawancara,danpertanyaan yang diajukan oleh peneliti kepada pihak-pihak yang berkepentingan dalam penelitian ini, maka peneliti dapat mengambil kesimpulan sebagai berikut : 
1. Pelaksanaan audit internal yang dilakukan oleh tim RIC perkreditan Bank Rakyat Indonesi Cabang Situbondo Kanwil VIII Surabaya telah sesuai dengan pedoman pelaksanaan audit internal yang ditetapkan oleh kantor pusat. Auditor intern (RIC) perkreditan yang dimiliki perusahaan mempunyaikedudukan yang independen terhadap bagian-bagian yang diperiksanya. Hal ini terlihat dengan tidak terlibatnya tim audit intern terhadap kegiatan operasional perusahaan. Pelaksanaan audit intern Bank Rakyat Indonesia Cabang Situbondo Kanwil VIII Surabaya telah mencakup verifikasi, compliance, dan evaluasi terhadap aktivitas pengelolaan kredit investasi. Pelaksanaan audit intern untuk kredit investasi dilaksanakan rutin minimal satu kali setahun, baik dilakukan dengan pemberitahuansebelumnya atau dengan surprise audit (bersifat urgent). Hal-hal tersebut membuktikan bahwa pelaksanaan audit internal atas kredit investasi pada Bank Rakyat Indonesia Cabang Situbondo. Kantor Wilayah VIII Surabaya telah memadai sehingga dapat mendorongtercapainyapengendalian internal perusahaan yang efektif. Berdasarkan kesimpulan penelitan ini tentang peranan audit internal dalam menunjang efektivitas pengendalian internal kredit investasi, masih banyak terdapat keterbatasan-keterbatasan yang harus diperhatikan oleh peneliti selanjutnya. Adapun keterbatasan-keterbatasan tersebut adalah :

\section{Keterbatasan Penelitian}

Peneliti merasa kesulitan untuk mendapatkan bukti seperti contoh kertas kerja pemeriksaan, surat penugasan pemeriksaan, dan dokumen bukti pendukung lainnya karena faktor kerahasiaan dokumen perusahaan. Penulis menyadari bahwa hasil penelitian yang telah disimpulkan di atas masih terdapat banyak kekurangan dan belum sempurna.

\section{Saran}

1. Diharapkan penelitian selanjutnya bisa mendapatkan lampiran bukti atau contoh kertas kerja pemeriksaan, surat penugasan pemeriksaan, dan dokumen bukti pendukung lainnya.

2. Diharapkan untuk peneliti selanjutnya tidak melakukan penelitian pada periode audit perusahaan, agar proses penelitian tidak memiliki hambatan 


\section{DAFTAR PUSTAKA}

Arrens, Alvin A., And Loebbecke., James K., 2000, Auditing And Integraed Approach, Eight Edition, Eglewood Clif, New Jersey. Prentice Hall Inc.

Azhar Susanto La Midjan. 1994. Sistem Informasi Akuntansi. Edisi Kedelapan. Bandung. Lembaga Informatika Akuntansi.

Cahill, Edward. 2006. “Audit Committee And Internal Audit Effectiveness In A Multinational Bank Subsidiary: A Case Study. Journal Of Banking Regulation" (Online), ( Journals.Com/Jbr/Journal/V7/N1/Abs/2340011a.Html)

Hiro Tugiman. 1997. Standar Profesional Audit Internal. Cetakan Ke-5. Yogyakarta. Kanisius.

Ihsan Kusumah. 2008. "Peranan Audit Internal Dalam Pencegahan Fraud". Skripsi Sarjana (Online). Bandung. Universitas Widyatama.

Ikatan Akuntan Indonesia. 2002. Standar Akuntansi Keuangan. Jakarta. Salemba Empat.

Iriyadi. 2004. "Peranan Internal Auditor Dalam Menunjang Efektifitas Sistem Pengendalian Intern Penggajian Pada PT. Organ Jaya”. Jurnal Ilmiah Ranggagading. Volume 4 No 2. Pp 67-72.

Kasmir. 2002. Dasar-Dasar Perbankan, Jakarta. PT. Raja Grafindo Persada.

K. Yin, Robert. 2003. Studi kasus; desain dan metode. Jakarta. PT. Raja Grafindo Persada

Mulyadi, dan Kanaka Puradiredja. 1998. Auditing. Edisi Ke-5. Jakarta. Salemba Empat.

Munawir, S. 2002. Analisa Laporan Keuangan. Edisi Ke-4. Cetakan Ke-5. Yogyakarta. Liberty.

Messier, Jr., William F., et al. 2005. Jasa Audit \& Assurance: Pendekatan Sistematis. Jakarta. Salemba Empat.

Palfi, Cristina. 2007. "Globalization - a challage for internal control and audit in banking system”. Globalization, Risks, Internal control system, Internal audit, Banking supervision Journal (Jurnal SSRN). Romania. Babeş-Bolyai University of Cluj-Napoca. 
Teguh Pudjo Mulyono. 1999. Bank Auditing: Petunjuk Pemeriksaan Intern Bank. Edisi Ke-5. Yogyakarta. Djambatan.

Thomas Suyatno, Dkk. 1995. Dasar-Dasar Perkreditan, Jakarta. PT.Gramedia Pustaka Utama.

Tjukria P. Tawaf. 1999. Audit Intern Bank. Jakarta. Salemba Empat.

Z. Dunil 2004. Risk-Based Audit: Dalam Pemeriksaan Bank Umum. Jakarta. Indeks. 